\title{
Mandatory Rules of Law in International Business Arbitration
}

\author{
S.M. Hyder Razvi
}

\begin{abstract}
Of all mankind's adventures in search of peace and justice, arbitration is amongst the earliest. Long before law was established, or courts were organised, or judges had formulated principles of law, man had resorted to arbitration for the resolution of discord, the adjustment of differences and the settlement of disputes.
\end{abstract}

One of the recurring themes in International Business Arbitration is the tension between the will of the parties and the ability of states of regulate the conduct of arbitration proceedings. The general trend in international commercial arbitration is to respect, within limits, the will of the parties regarding the choice of law and the procedure for carrying out their arbitration. Thus, party autonomy is recognised as one of the cardinal elements of international business arbitration.

The past decade has witnessed an expansion in the scope of arbitrable matters. Such expansion is exemplified by Mitsubishi Motors Corp. V. Solar 1 Chryster-Ohlymoutt ${ }^{1}$ in which the United States Supreme Court held that antitrust disputes arising from international contracts are arbitrable. The court reached this conclusion against the background of a number of U.S. cases which considered antitrust law fundamental to the ideological and economic integrity of the United States. ${ }^{2}$ Underlying the Supreme Court's decision in Mitsubishi was the presumption that the arbitrators in the case would respect the imperative provisions of the U.S. Sherman Act (which embodies U.S. antitrust principles), despite the fact that the applicable law in the case was Swiss Law.

It thus seems that the increasing acceptance of international arbitration as a respectable alternative to litigation implies an expectation on the part of States that arbitrators will, like judges, respect the basic notions of justice, and in appropriate cases apply the mandatory provisions of relevant laws. It is one thing to grant parties the power to organise their objectives, but it is a different matter to suggest that parties to an

${ }^{1} 473$ U.S.S. 625 (1985) Stamford Ct.

${ }^{2}$ See United States V. Aluminum Co. of America (Alcoa) 148 F.2d 416. Indeed the court in American Safety Equipment Corp. V. J.P. Maguire and Co. 391 F. $2 d 821$ at 827-828, held that antitrust disputes were non arbitrable in view of "the pervasive public interest in the enforcement of antitrust laws. 
international arbitration are entirely free from the demands of public policy and other fundamental provisions of the relevant laws. ${ }^{3}$ The integrity of international arbitration and its endurance as a viable alternative to litigation would seem to rest on the arbitrator's continual respect for the public policy of States whose legitimate interests are implicated in arbitration disputes. Arbitrators therefore have to balance their respect for the autonomy of the parties' will with the need to apply mandatory provision of laws which are relevant to the dispute.

Here, I will examine the impact of mandatory rules in resolving the merits of a dispute before international arbitrators. The problem posed by mandatory rules in international arbitration will be put in perspective by contrasting the position of international arbitrators with those of national judges called upon to enforce imperative laws. Therefore, the discussion will focus on the discernible trends in the application of mandatory rules in international arbitration. This is done by examining the treatment of mandatory rules of the lex contractus and mandatory rules of laws external to the lex contractus. The research concludes with an examination of the role of transnational public policy (which, in a sense, is the mandatory rule of the international legal order) on the determination of the merits of a dispute.

\section{When is an Arbitration International?}

The determination of whether an arbitration is international or domestic (national) is often significant because most countries have different legal regimes to govern each type of arbitration. The word international is to distinguish domestic arbitration from those which in some way transcend national boundaries. ${ }^{4}$ International arbitrations usually have a foreign element to them, and most countries treat such arbitrations much more liberally than they do arbitrations with purely domestic elements. The liberal treatment of international arbitrations includes greater respect for the expressed intentions of the arbitrating parties, and far less judicial intrusion in the arbitration process than is the case in domestic arbitrations.

There are two main methods used in determining whether an arbitration is international: the identity of the parties and the nature of the dispute.

\footnotetext{
${ }^{3}$ As A. Bucher and P. Tschanz remind us:

"States that favour international arbitration as a means of resolving international commercial disputes do not by the same token forego compliance with principles and rules which are fundamental for the economic and social system. The fact that arbitral tribunals are allowed to adjudicate disputes instead of courts does not mean that arbitration can enerve the legislative power of States.”

International Arbitration in Switzerland (Basle: Helbing \& Lichtenhahn, 1989.

${ }^{4}$ A. Redern \& M. Mhunter (Settlement of International Business Disputes) at 14.
} 


\section{Identity of the Parties}

The method focuses on the identity of the arbitrating parties: their nationality or habitual place of residence, if they are individuals; or their place of incorporation or the seat of their management and control, if they are corporate entities. This approach is exemplified by the European Convention on International Commercial Arbitration which applies to arbitration agreements concluded for the purpose of settling disputes arising from international trade between physical and legal persons having, when concluding the agreement, their habitual place of residence of their seat in different contracting states.

The Swiss Law governing international commercial arbitration incorporates this approach. Article 176(1) of the Swiss Private International Law Act limits the application of the chapter on international arbitration to cases where the seat of arbitration is situated in Switzerland and, at the time the arbitration agreement was concluded, at least one of the parties had neither its domicile nor its habitual residence in Switzerland.'

This method of defining international arbitration is very limiting in that it excludes some situations where the dispute being arbitrated has a foreign element. For example, parties resident in the same country may have a dispute about a subject matter located in a foreign country. Focusing on the identity of parties in cases like this obscures the fact that the nature of the subject matter in dispute imports an international element into the dispute an element that may be crucial in the resolution of the dispute. This method also categorises as domestic cases involving a foreign party who has a representative place of business in the country of the other party. For example, a transactional corporation based in the United States may have a representative office in Toronto through which it deals with its Toronto customers. To characterise an arbitration between such a corporation and one of its Toronto customers as domestic fails to reckon with the fact that the dealings between the parties are, as a practical matter, of an international nature.

\section{The Nature of the Dispute}

This criterion examines the nature of the dispute between the parties and categorises the arbitration as international if the dispute implicates international commercial interests. The International Chamber of Commerce (ICC) was the first to adopt this criterion. Article 1.1 of the ICC

\footnotetext{
${ }^{5}$ A similar approach is adopted in England, albeit in an indirect manner. See Redfern \& Hunter, at 12.
} 
Rules defines the functions of the Court of Arbitration of the ICC as the provision of a forum for the "settlement by arbitration of business disputes of an international character". According to an ICC publication:

The international nature of the arbitration does not mean that the parties must necessarily be of different nationalities. By virtue of its object the contract can nevertheless extend beyond national borders, when for example a contract is concluded between two nationals of the same state for performance in another country, or where it is concluded between a State, and subsidiary of a foreign company doing business in the State. ${ }^{6}$

The test is adopted by French Law. The French Code of Civil procedure provides that "an arbitration is international if it involves international commercial interests" ${ }^{\prime 7}$, although it does not define what international commercial interests are.

The nature of the dispute test is less artificial than the identity of the parties test because it concentrates on the attributes of the dispute, thereby embracing cases where parties resident in the same country engage in international business transactions.

The Model Law on International Commercial Arbitration sought to harmonise state practice in relation to the definition of international arbitration. It rejected the idea of a single formula, and provides four alternative tests for determining when an arbitration is international:

A dispute is international if:

(a) the parties to an agreement have, at the time of the conclusion of that agreement, their places of business in different states; or

(b) one of the following places is situated outside the State in which the parties have their place of business:-

(i) the place of arbitration if determined in, or pursuant to, the arbitration agreement;

(ii) any place where a substantial part of the obligations of the commercial relationship is to be performed or

\footnotetext{
${ }^{6}$ The International Solution to International Business Disputes - ICC Arbitration (ICC Publication No. 301, 1977) at 10.

${ }^{7}$ Article -1492 .
} 
the place with which the subject matter of the dispute is most closely connected; or

(c) the parties have expressly agreed that the subject matter of the agreement relates to more than one country. ${ }^{8}$

The definition adopts both the identity of the parties and the nature of dispute tests, in addition to two other ones: the 'suits test' (the situation of the proceedings outside the place of business of one of the parties) and the 'opt-in test' (the parties expressly agree that the subject matter of the arbitration agreement relates to more than one country). This definition effectively expands the test of internationality, although the opt-in provision may create some difficulties.

The opt-in clause gives the parties the opportunity to internationalise an arbitration with exclusively domestic elements merely by stating that "the subject matter of (their) arbitration agreement relates to more than one country. "This provision is objectionable in that nationals of the same State seeking to escape the mandatory provisions of their country in order to internationalise their proceedings. There is evidence that the drafters of the Model Law were aware of this possibility:

It was understood that the States would be prepared to allow the 'opting-in' only if an element of internationality is present. Such elements should have been that not all of the following places are situated in the same State: place of offer of contract containing the place of settlement clause or of separate arbitration agreement; place of corresponding acceptance; place of performance of contract or of location of subject matter; place of registration incorporation or nationality of each party; place settlement.

However, the final draft of the Model Law fails to incorporate the above requirements, with the result the arbitrating parties could declare an otherwise domestic arbitration to be international. In response to this point, two commentators assert that "domestic arbitration laws tend to provide protection that are not needed by sophisticated parties likely to use the optin provision". This observation misses the point; the issue is not the sophistication of the parties, but their ability to circumvent mandatory rules which are specifically designed to regulate domestic arbitrations - a category in to which their arbitration may otherwise fall. No doubt many countries will find it difficult to accept a situation where parties might internationalise

${ }^{8}$ Article 14 (ICC-Paris)

${ }^{9}$ H. Holtzmann \& J.Neuhaus, A. Guide to the UNCITRAL Model Law on International Commercial Arbitration (The Netherlands: Kluwer Law \& Taxation Publishers, 1984) at 43. 
an arbitration which is otherwise purely domestic. It should be noted, however, that under the framework of the Model Law, their exist possible avenues for dealing with parties who abuse the option provision. Under Article 8 , courts may refuse to refer such cases to arbitration, or exercise the power to set aside or refuse enforcement of any resultant award as being contrary to public policy under Article 34 and 35.

In summary, the identity of the parties and the nature of the dispute are the two main methods of determining when an arbitration is international, although the Model Law introduces additional methods. It is crucial to remember that the answer to the question whether an arbitration is domestic or international is always to be found in the provisions of the relevant national law.

\section{Reasons for the Increasing Use of Arbitration}

The post World War II era has witnessed a considerable expansion in the level of international trade and commerce. This process has been tremendously aided by the General Agreement on Tariff barriers to trade. The level of international trade in goods and services continues to increase daily. In relation to developing countries, there is a continuing, if often sporadic, inflow of foreign investment such as capital, joint ventures, turnkey and technology transfer agreements.

\section{Mandatory Rules Defined}

Traditional conflict theory postulates that a statute is inapplicable to a contract unless the statute forms a part of the proper law of the contract or is otherwise applicable as part of the procedural laws of a forum court. However, it has long been accepted that this proposition is subject to the qualification that imperative laws of the forum may apply to contract irrespective of the proper law of the contract. Thus, one of the limitations on party autonomy within a national legal system is that overriding Laws of the forum may override the laws chosen by the parties. ${ }^{10}$

It is these rules of law which are capable of overriding the will of parties that are labelled "mandatory rules denote those rules of law that

\footnotetext{
${ }^{10}$ As A. Maniruzzaman puts it: Although the parties' freedom of choice (autonomy of will) is a general principle of private international law and is to be respected in principle, it should operate within the limits imposed by such other equally important general principles of law or subject to any restraints of public policy. International arbitrator and Mandatory Public Law Rules in the Context of State Contracts: An Overview (1990) 7:3 J. Int'l Arb.
} 
parties cannot derogate from, rules which in appropriate cases supersede the proper law, thereby substituting their provisions for the will of the parties:

[a] mandatory rule is a rule which overrides the normally applicable law (or .. the proper law of the contract) whether that applicable (proper) law is ascertained by reference to an express stipulation or by reference to the closest connection. In short it is a law which applies irrespective of or despite the proper law of a contract." 11

These rules embody the fundamental public policy of a given State and are therefore applicable by virtue of their imperative nature. They typically regulate matters in which the interest of the State is too important for them to be in competition with foreign laws" ${ }^{12}$ or the will of the parties. ${ }^{13}$ Thus there is a close relationship between the concept of public policy and that of mandatory rules. Mandatory rules would include those aspects of public policy that lie within the superstructure of a legal system and which, because they reflect the basic social and economic philosophy of a State, are framed in an imperative manner. These include currency and exchange regulations, boycotts and blockades, and environmental protection laws.

Examples of mandatory rules abound in national laws. In Australia, for example, the Consumer Transaction Act applies to a consumer contract involving the delivery of goods in South Australia irrespective of the proper law of the contract. Similar provisions are to be found in the English Employment Protection (Consolidation) Act, ${ }^{14}$ the English Uniform contract Terms Act, and the German Regulation of Standard Contract Terms Act. ${ }^{15}$

\section{Treatment of Mandatory Rules in national Courts}

Owing to the fact that a national court's allegiance lies with the legal system of its situs, a national court is constrained to apply the

\footnotetext{
${ }^{11}$ See M. Prylees, "Reflection on the E.E.C. Contractual Obligations Convention - An Australian Perspective" in P. North (ed.) Contract Conflict: The E.E.C. Convention on the law Applicable to contractual Obligations, A Comparative Study (The Netherlands: North-Holland Publishing, 1982).

${ }^{12}$ Y. Derains, "Possible Conflict of Law Rules and the Rules Applicable to the Substance of the Dispute" in P. Sanders (ed.) UNCITRAL's Project for a Model Law of International Commercial Arbitration (Deventer, the Netherlands: Kluwer, 1984) 169 at 179.

${ }^{13}$ Article 3(3) of the EEC Convention on the Law Applicable to Contractual Obligation defines mandatory rules as "rules of law of a country which cannot be derogated from by contract." For a discussion of the convention, see P. North, supra note 5.

${ }^{14}$ See A. Anton and P. Beaumont, Private International Law, 2nd ed. (Edinburgh: W. Green, 1990) at 343.

${ }^{15}$ See V. Tribal, "The Choice of Law in Commercial Relations: A German Perspective" (1988).
} 
fundamental public policy of that system to disputes before it. Thus, a national court would apply the public policy and mandatory rules of its situs regardless of the proper law of the contract involved. The court system is one of the vehicles through which a society expresses and protects those fundamental values which underlie its social fabric. National courts therefore apply imperative rules which invariably represent the essential values of their societies, even in cases where the forum laws do not govern the contract.

Fundamental public policy has a dual aspect in its impact on judicial proceedings. The first, and perhaps the more common aspect, is that it compels a national court to deny recognition to an applicable foreign law which contravenes the stringent public policy of the forum. Second, it mandates the national court to give effect to those national legislation which, by their provisions, govern all contacts regardless of the proper law of the contract. An example of this kind of legislation is the Australian Consumer Transactions Act cited above.

Under the first aspect, the applicability of foreign governing laws is determined by their conformity with the stringent public policy of the forum. ${ }^{16}$ This rule was stated by Lord justice-Clerk Patton in Cannal \& Co. V. Loder.

Everybody knows that the fundamental principle upon which we introduce foreign law as affecting the rights of contracts or otherwise, is only to the effect of introducing such law when it is not in direct contradiction to the principle upon which our law is governed, and according to which the rights of the subjects in this country must be determined. ${ }^{17}$

It is generally accepted that this use of public policy should be highly circumscribed. Specifically, public policy is viewed as disabling the application of otherwise applicable law only in cases where the foreign law

\footnotetext{
${ }^{16}$ See Ross V. McMullen (1971) 21 D.L.R. (3d) 228.

${ }^{17}$ Id. At 1110. This principle is contained in Rules 2 of Dicey and Morris conflict of Laws: English courts will not enforce or recognise a right, power, capacity, disability or legal relationship arising under the law of a foreign country, if the enforcement or recognition of such right, power, capacity, disability or legal relationship would be inconsistent with the fundamental public policy of English law.

7th ed. (London: Stevens \& Sons, 1987) at 92. Stating the Canadian position on the issue, J. Castel notes that Canadian courts will not recognise or enforce a right or power that is "contrary to the forum's stringent public policy or essential public or moral interest." Canadian Conflict of Laws, 2nd ed. (Toronto: Butterworts, 1986) at 153. In a similar vein, Article 17 of the Swiss Federal Statute of Private International Law provides that "The application of provisions of a foreign law is excluded if the outcome is incompatible with Swiss public policy.”
} 
offends the forum's essential and basic policy interest. As the court in Loucks V. Standard Oil Co. Put it:

"The courts are not free to refuse a foreign right at the pleasure of the judges, or suit the individual notion of expediency or fairness. They do not close their doors unless help would violate some fundamental principle of justice, some prevalent conception of good morals, some deep-rooted tradition of the common weal." 18

Under the second aspect of public policy, in dealing with a contract containing a foreign choice of law, a national court would apply those laws of the forum which by their provisions are designed to apply to all disputes litigated in the forum which fall within their scope. Here the court has no discretion whether or not to apply the mandatory rule because, as a creature of the national legal system, its jurisdiction and powers are regulated by national law. It must therefore apply all imperative laws of its forum. To illustrate, a court in South Australia dealing with a contract for delivery of goods in South Australia must apply the Consumer Transaction Act, whatever the contractual stipulations of the parties or the provision of the proper law chosen by them.

\section{The Particular Position of Arbitrators}

Unlike national courts, international arbitral tribunals do not owe allegiance to the laws of the place of arbitration, neither are they constituted by the laws of the arbitral seat. Indeed, they do not have a forum in the same way as national courts do. An arbitral tribunal could decide to conduct the arbitration proceedings in different countries, in which case it is unrealistic to categorise the public policy of any of the fora as applicable to the dispute. Even in case where the proceedings are held in one country, international arbitrators still do not, as a theoretical matter, owe allegiance to the laws of that situs, in the sense that they are not constrained to apply all the imperative rules of the forum in the same way that national courts are.

\footnotetext{
${ }^{18}$ Block Bros. Realty Ltd. V. Mollard (1981) 4 W.W.R. 65. There is a trend towards drawing a distinction between domestic public policy and international public policy in the recognition of foreign law. In this respect, non-recognition of foreign law on grounds of public policy would be based not on the internal rules of public policy in the forum, but on the foreign law's inconsistency with the forum court's view of public policy in international matters.
} 
It is said that an arbitrator's responsibility is to the arbitrants in particular and the international business community in general. ${ }^{19}$ This view originates from the fact that the power and authority of arbitrators are primarily derived from the agreement of the parties. Since their authority is derived from the will of the parties, it is argued that arbitrators have a duty, first, to affirm the will of the parties, and, second, to further the interests of international commerce. This implies that arbitrators have to give primacy to the will of the parties while respecting the basic philosophy and principles of international commerce:

International commercial arbitrators are the guardians of the international commercial order: they must protect the rights of participants in international trade, give effect to the parties' respective obligations under the contract; imply the presence of commercial bona fides in every transaction; respect the customs followed in international trade practice and the rules developed in relevant international treaties; uphold the commonly accepted views of the international commercial community and the policies ${ }^{20}$ expressed and adopted by appropriate international organisations; and enforce the fundamental moral and ethical values which underlie every level of commercial activity.

Does this mean that arbitrators are free to ignore the mandatory rules of relevant national laws? While it is true that the jurisdiction of international arbitrators depends on the agreement of the parties, it is also true that arbitration would lose its respect and legitimacy as a dispute resolution system if arbitrators continually ignore the mandatory national laws that are connected with arbitral disputes. States that allow the arbitration of sensitive matters, such as antitrust disputes, do so on the assumption that arbitrators arbitrating antitrust disputes which are substantially connected to their jurisdictions would apply the relevant antitrust laws of these jurisdictions. If arbitrators reject the application of these mandatory laws, there is little doubt that these States would move to make such sensitive matters non-arbitrable.

${ }^{19}$ See J. Lew, Applicable Law in International Commercial Arbitration: A Study in Commercial Arbitration awards (New York: Ocean Publications, 1978) at 536. This principle may well be overstated in that an arbitral tribunal still owes a duty to the various national legal systems: a duty to ensure that arbitration proceeding conform with basic notions of justice and fairness.

${ }^{20}$ L. Colin 


\section{Mandatory Rules of the Lex Contractus}

Arbitrators generally apply the law chosen by the parties. ${ }^{21}$ Thus, when the parties have made an express choice of law, the arbitrators apply that law together with its mandatory rules. In most awards in which the applicability of the mandatory rules of the law chosen by the parties arose, arbitrators applied those rules as a matter of fact. ${ }^{22}$

It is, however, possible to conceive of a situation where an arbitrator need not apply the mandatory rules of the law chosen by the parties. An example would be cases where the underlying purpose and objective of the rule indicate that it is aimed at purely domestic situations as opposed to cases involving international disputes. Additionally, an arbitrator may decline to apply a mandatory rule of a law chosen by the parties in the unlikely event that the rule is contrary to "transnational public policy". ${ }^{23}$

An interesting issue in this area of arbitration is whether arbitrating parties can legitimately exclude the application of agreement. In effect, can the parties slice off unacceptable portions of the governing law of their contract? In theory, it could be argued that since the parties selected the governing law, they could as well determine which parts of the law would govern their agreement; after all they could very well have chosen another law as the governing law. And since the arbitrators are bound to apply the law chosen by parties, they have no choice but to respect the will of the parties.

This theoretical argument however ignores the basic fact that as hackneyed as the concept of party autonomy is, it has its limitations. Maniruzzaman reminds us that:

Although the parties freedom of choice (Autonomy of will) is a general principle of private international law and is to be respected in principle, it should operate within the limits imposed by such equally important general principles of law or subject to any restraint of public policy. ${ }^{24}$

The will of the parties is not sacrosanct. The parties' will prevails so far as it is consistent with relevant public policy. Consequently, since mandatory rules are designed to apply regardless of the parties' choice of governing law,

${ }^{21}$ W. Craig, W.l Park and J. Paulsson, International Chamber of Commerce Arbitration, 2nd ed. (New York: Oceana Publications, 1990) at 307-308.

${ }^{22}$ See, for example, ICC Case No. 1397 (1966) Clunet 878.

${ }^{23}$ The concept of "transnational international public policy" and its effect on the application of mandatory rules of national law is discussed below.

${ }^{24}$ A. Maniruzzaman. 
arbitrators may legitimately refuse to recognise the parties' exclusion of mandatory rules of the lex contractus in cases where the parties' transaction is very closely connected with the jurisdiction whose law is the lex contractus and the mandatory rules were designed to regulate such transactions. For example, if a Canadian company enters into a distribution agreement with a Japanese auto company for the distribution of cars in Ontario (and the parties chose Ontario law as the applicable law), an arbitral tribunal may refuse to apply a contractual provision excluding Canadian competition laws. To respect the parties' will in such a case would be tantamount to the subjugation of the country's legitimate interest in regulating its business environment to the interest of private contracting parties.

What about cases where the lex contractus is chosen by the arbitrators in the absence of an express choice by the parties? Since the conflict rules used in determining the applicable law in the absence of the parties' express choice focuses on the law of the country with which the contract is most closely connected, it would seem that an arbitral tribunal should apply the mandatory rules of the law of such a country. This is because the transaction would invariably have a notable impact on that country. However the arbitrator may have to balance the interests of this country with those of other countries that are equally connected with the transaction.

\section{Mandatory Rules Foreign to the Lex Contractus}

Mandatory rules foreign to the lex contractus are those of jurisdictions other than that whose law governs the merits of a dispute. Thus if New York law governs a dispute, the mandatory rules of jurisdictions other than New York are classified as foreign mandatory rules.

In examining the treatment of mandatory rules foreign to the lex contractus, it is useful to draw from the experience of national judicial systems as the issue has more commonly arisen before them. The attitude in most common law jurisdictions is that a mandatory rule shall not be applied unless it is part of the laws of the forum or form part of the governing law of the contract. Stating the law in England, the editors of Dicey and Morris Conflict of Laws note that "Where a mandatory law is neither legislation of the forum nor of the applicable law it has no application in England". ${ }^{25}$ This position is the same in Australia, ${ }^{26}$ but unclear in Canada. The United States position is somewhat more liberal in its treatment of foreign mandatory

\footnotetext{
${ }^{25}$ L. Collins

${ }^{26}$ See E.Sykes and M. Pryles, Australian Private International Law, 2nd ed. (Sydney: The Law Book company, 1987) at 546. See also M. Pryles, supra note 5 at 330.
} 
rules in that the American Restatement of Conflict of Laws allows for the application of the mandatory rules of a State "which has a materially greater interest than the chosen State in the determination of the particular issue" and which, under the forum's law, would have been the applicable law in the absence of an express choice by the parties. The reluctance of most common law jurisdictions to fully accept the application of foreign mandatory rules is often based on the grounds that recognition of such rules would cause uncertainty in that the parties would not be able to determine before hand the rules that might affect their transaction. ${ }^{27}$

Civil law jurisdictions, on the other hand, are more receptive to the application of foreign mandatory rules. The civil law approach is exemplified by Article 19 of the Swiss Federal Statute on Private International Law which provides, inter alia:

(1) A provision of a law, other than the one designated by this statute, that is meant to be applied mandatorily may be taken into account if interests of a party that are, according to Swiss views, legitimate and clearly overriding so require, and the case is closely connected to that law. ${ }^{28}$

Similarly, Dutch law recognises the possibility of applying the mandatory law of a third State irrespective of the parties choice if "it is in the interest of [the] foreign State that some of its rules be observed outside its territory". ${ }^{29}$ German courts also acknowledge the possibility of applying foreign mandatory law. In one case, the German BGH applied a Nigerian mandatory law prohibiting the export of art objects, even though Nigerian law did not govern the contract. ${ }^{30}$

Thus, while civil law jurisdictions are generally receptive to the application of foreign mandatory rules, common law jurisdictions are reluctant to apply such rules. However, it should be noted that even in those countries in which the application of foreign mandatory rules is not fully acknowledged, it is generally accepted that "the mode of performing a contract, as distinct from the substance of the obligation, is governed by the law of the place of performance (the lex loci solutions)".

${ }^{27}$ See, for example, A. Anton \& P. Beaumont.

${ }^{28}$ P. Karrer and K. Arnold, Switzerland's Private International Law Statute, 1987 (Deventer, The Netherlands: Kluwer Law Taxation Publishers 1989) at 44-45.

${ }^{29}$ R. Rooij and M. Polak, Private International Law in the Netherlands (Deventer, the Netherlands: Kluwer Law and Taxation Publishers, 1987)at 129.

30 See E. Jayme, "The Rome Convention on the Law Applicable to Contractual Obligations (1980)" in P. Sarcevis (ed) International Contracts and Conflict of Laws (London: Graham \& Trotman, 1990) at 46-67. 
This rule is justified by the assumption that the parties must have "intended to incorporate in their contract those parts of the law of the place of performance which refer to the manner in which the contractual obligations are to be discharged." Thus, where, for example, a Canadian company has a contractual obligation to build an industrial complex in Nigeria, rules would determined the formalities required for the erection of such a complex, and other issues such as building codes and employment standards.

Arbitral practice follows this dichotomy between the civil and common law jurisdictions in regard to the application of foreign mandatory rules. The arbitral practice there is both a hostile and a favourable approach towards the application of foreign mandatory rules, although there is a common acceptance of the role of the lex loci solutions in determining the mode of performance. Let us first examine the two divergent approaches to the application of foreign mandatory rules in arbitration proceedings.

The hostile approach is premised on the ground that arbitrators are bound by the will of the parties and are therefore obligated to apply only the law chosen by the parties, or, in the absence of such a choice, the law chosen on their behalf by the arbitrators. ${ }^{31}$ Consequently, the advocates of this approach contend that arbitrators are barred from applying laws outside the lex contractus. They further suggest that as arbitrators are not custodians of public interests (their obligation is to the parties), they should not apply foreign mandatory rules ${ }^{32}$ which reflect the public policy of foreign mandatory rules (a reason which is borrowed from common law jurisprudence) is that their application would lead to uncertainty as the parties would not know before-hand which mandatory rules the arbitrators may decide to apply to their case.

This writer believes that the hostile view gives an overly important weight to the will of the parties. As stated above, the will of the parties is not sacrosanct; it may in appropriate cases give way to the legitimate

\footnotetext{
${ }^{31}$ This approach is illustrated by some awards. In ICC Award No.1399, the arbitrators, considering the validity of a contract which had the indirect object of circumventing Mexican customs law, held that the proper law of the contract (French Law) could not be displaced by Mexican law, the law of the place where the goods in dispute were to be imported. See J. Lew, supra note 17 at 550-551. Similarly, in an award rendered by the arbitration court of the Chamber of Foreign Trade of the defunct German Democratic republic [(1979) IV Y.Comm., Arb. 197], the arbitrators in determining the validity of a license agreement between firms in the CDR and the Federal Republic of Germany, held that competition laws of the FRG were inapplicable because the contract was governed by the laws of the GDR.

${ }^{32}$ I have designated mandatory rules outside the lex contractus as foreign mandatory rules because they are external to the governing law.
} 
concerns of those States whose interests are implicated by the dispute. To adopt an earlier example, where Canadian competition policy is central to the determination of a dispute involving the importation of automobiles into Canada, it would be unreasonable for an arbitrator to refuse to apply that policy on the flimsy ground that the governing law of the contract at hand say for instance, is Japanese law. The principle of party autonomy ought not to override Canada's cogent public interests in such a case.

One commentator queries whether the principle of party autonomy is "so hallowed that in all cases it would be limited only by the law of the parties' selection?" ${ }^{33}$ The answer is certainly no, for "justice is not always to be controlled by the individual as distinct form the community of which the individual is a part."

Furthermore, the application of foreign mandatory rules is not invariably antithetical to the wishes of the parties. As Derains rightly points out, the choice of one law does not necessarily imply an intention to exclude all relevant mandatory rules that are external to the chosen lex contractus. ${ }^{34}$ It may well be that the parties intended their agreement to conform to the mandatory rules of those countries upon which their transactions have a significant impact. For example, in the above illustration, the parties may have selected Japanese law to govern their agreement on the understanding that despite this selection, Canadian competition laws would be repeated.

More importantly, the will of the parties cannot be used as a ground or refusing to apply the mandatory rules of foreign law as the parties in many cases do not express any view on the applicability of foreign mandatory rules. The choice of a governing law should not be interpreted as implying the exclusion of other relevant laws, unless the parties expressly exclude them. Even then, the parties can legitimately override the public interests of a country whose jurisdiction is substantially connected to the underlying transaction.

Finally, the plea of uncertainty as a justification for non-application of foreign mandatory rules sites a little ill when it is remembered that other principles of law are no less certain. For example, in the absence of an express choice by the parties, arbitrators usually apply the law most closely connected to the contract. Certainly, this process of determining applicable law does not afford certainty of application. More importantly, one wonders

${ }^{33}$ D. Jackson, "Mandatory Rules and Rules of "Odre Public"” in P. North.

${ }^{34}$ Y. Derains, "Public Policy and the Law Applicable to the Dispute in International Arbitration" in P. Sanders (ed) Comparative Arbitration Practice and Public in Arbitration (The Netherlands: Kluwer Law and Taxation publishers, 1987 at 249. 
why the need for certainty should supersede the necessity of respecting the mandatory rules of foreign laws which are substantially connected to the dispute. The application of foreign mandatory rules should involve a balancing of the public interests of the enacting State with the private interests of contracting parties.

In contrast, the favourable approach to the application of mandatory rules (to which this writer subscribes) recognises the fact that foreign mandatory rules may be so connected with the dispute as to compel their application, whether or not they are part of the governing law. This approach, acknowledging the fact that the will of the parties has to be reconciled with the interests of those States which are closely connected to the dispute, entertains the possibility of applying foreign mandatory rules in appropriate cases.

The favourable approach is accepted in most of the recent Conventions dealing with contractual relations. An example is Article 7 or the European Convention on the Law Applicable to Contractual Obligations (the Obligation Convention) ${ }^{35}$ which provides that:

When applying under this Convention the law of a country, effect may be given to the mandatory rules of the law of another country with which the situation has a close connection, if and in so far as, under the law of the latter country, those rules must be applied whatever the law applicable to the contract. ${ }^{36}$

A similar approach is also adopted in Article 16 of the Hague Convention on the Law Applicable to Agency:

In the application of this Convention effect may be given to the mandatory rules of any State with which the situation has significant connection, if and in so far as, under the law of that State, those rules must be applied whatever the law specified by its choice of law rules.

These conventions are of course not directly applicable to arbitration proceedings, but they represent an emerging consensus on the need to respect the imperative rules not only of the proper law but also other laws

\footnotetext{
${ }^{35}$ Opened for signature in Rome on June 19, 1980. The Convention does not, however apply to "arbitration agreements": Article 1 (2) (d).

${ }^{36}$ This provision is considered imprecise, vague and controversial by those who favour the English approach of not applying foreign mandatory rules. See-1. Fletcher, conflict of law and European Community Law (Amsterdam: North-Holland Publishing, 1982) at 170. According to Article 22(1) (a) of the Convention, a Contracting State may reserve the right not to apply Article 7(1). Exercising this right, the United Kingdom and Germany excluded Article 7(1).
} 
that are significantly connected to the transaction. O. Lando rightly sees in the obligation convention the embodiment of a reasonable principle that is extendable to international commercial arbitration:

Article 7(1) of the Obligation Convention is expressive of international solidarity. States should help each other in the enforcement of relevant government policies. The arbitrators should contribute to this solidarity by giving effect to mandatory provisions claiming application, provided that those rules are enacted by a State having a close relationship with the contract and that it is fair and reasonable to give effect to them. ${ }^{37}$

In applying foreign mandatory rules, arbitrators should first weigh the connection of the rules to the dispute, with the aim of determining if the parties' transaction is substantially connected to the country which enacted the mandatory rules. Secondly, they should ascertain that the policy behind the rules demonstrate that the rules are applicable to international commercial transactions. Arbitrators should place particular emphasis on the policy rationale for the rules because in many cases mandatory rules are designed solely for domestic application. The obligation convention endorses this approach by stating that in deciding whether to apply mandatory rules, "regard shall be had to their nature and purpose and to the consequences of their application or non-application." ${ }^{38}$ Similarly, Swiss judges applying foreign mandatory rules examine their "policy and consequences for a judgement that is fair according to Swiss views." 39

The utilisation of the nature and purpose of a mandatory rule as a guide in determining its application would invariably lead to the application for the law of the place of performance. This is because the parties should be presumed to act on the understanding that the contract would be performed in accordance with the rules of the country where performance is required. Arbitrators will doubtless be reluctant to require a party to perform a contract, or pay damages for non-performance, where the mandatory rules of the place of performance makes it impossible to do so. ${ }^{40}$

The attitude of arbitrators to the mandatory rules of the place of performance is illustrated by the award in ICC Case No. 1859 where the tribunal stated:

\footnotetext{
${ }^{37}$ O. Lando, at 159.

${ }^{38}$ Article 7(1).

39 Article 19(2) of Switzerland's Private International Law Statute, 1987.

${ }^{40}$ W. Caraig, W. Park \& J. Paulsson, at 304.
} 
Since the contract must be performed in Lebanon, Syria and Jordan, it is a sure fact that the Lebanese importer was obliged to comply with the mandatory rules of the countries of importation and that the Japanese party cannot now claim that those rules cannot be raised against him.

Any merchant of a country who attempts to sell his products in another country is bound to respect the mandatory rules of the country of reception and cannot claim to be unaware of or not respect police laws or the regulation governing the importation of its goods, particularly when this law or regulation existed at the time of the performance of the contract. ${ }^{41}$

Also, in ICC Case No. $761^{42}$ one of the parties argued that since the contract was contrary to public interest, therefore it is void according to French law, the law of the place of performance. The tribunal held that in so far as the contract was relevant to the case, it found that the instant contract did not violate French public policy.

However, the case is somewhat more delicate when the foreign mandatory rule involved is not that of the place of performance. Nevertheless, the purpose of the rule and its connection to the dispute are very helpful indicators for the legitimacy of its claim to application. Assume that a Canadian party enters into a contract with a U.S. citizen for the building of a casino in Bermuda. The contract is governed by English law. In proceeding before arbitrators, the Canadian party pleads Ontario's prohibition of gambling as vitiating the contract. In a case like this, the arbitrators should be guided by the nature and purpose of the mandatory rule in question and the extent of its connection to the case. In the instant case, the only connection of Canada to the case is that it is the residence of one of the parties. On the other hand the place of performance and governing law have no connection with Canada. Clearly, Canadian laws do not have any legitimate claim to application in the case. Additionally, a finding that Ontario's prohibition of gambling is aimed at domestic situations would fortify the decision not to apply Ontario law.

The application of foreign mandatory rules is particularly crucial in cases involving sensitive state policy, such as competition laws or environmental laws. Here arbitrators should ensure that arbitration does not become a vehicle for avoiding the application of the mandatory rules of countries significantly connected to the underlying transaction.

${ }^{41} 1973$ Rev. Arb. 122.

${ }^{42}$ Reported in J. Lew, at 542. 
Nevertheless, the application of foreign mandatory rules should be rejected in cases where they lack a substantial connection with the underlying transaction or where their nature and purpose argue against their application to the international arena. ICC Case No. $4132^{43}$ illustrates the application of this principle. In a dispute between an Italian and a Korean party (governed by Korean law), the arbitrators declined to apply European competition law because the contract did not have a significant effect in Europe.

Since the Agreement is a contract between an Italian and a Korean undertaking and was for a larger part performed in Korea, this Tribunal is not satisfied that the Agreement may affect trade between Member States (of the European Community)......

Similarly, in a 1982 award of the Amsterdam grain Trade Association, ${ }^{44}$ the arbitral tribunal noted that the application of a foreign mandatory rule depends on its "nature and extent" and the "consequences of its appellation or inapplication". It held inapplicable the mandatory rule of one of the parties' nationality on the grounds of lack of substantial contact with the agreement. The relevant connecting factors in the case pointed to the Netherlands and Germany, and the party's Austrian nationality was, on it own, insufficient to warrant the application of Austrian mandatory rules.

Also in ICC Case No. $1512,{ }^{45}$ in an action to enforce a guarantee issued by a Pakistani bank in favour of an Indian company, the Pakistani bank pleaded in a defense certain Pakistani decrees making any payment to an Indian, the tribunal held that "Pakistani law, the law of the place of the debtor's residence, should not intervene." The arbitrators focused on the particular issue trained in the case, namely, that of payment under the guarantee. Since that particular element was not connected to Pakistan, the Pakistani prohibition could not effect the performance of the contract in Indian territory.

In conclusion, it could be seen that the major trend in arbitral practice is to apply foreign mandatory rules in appropriate cases. The application of these rules in individual cases depends on their connection with the dispute and their nature and purpose.

\footnotetext{
${ }^{43}$ S. Jarvin \& Y. Derains Collection of ICC Arbitral Awards, 1974-1985 (Deventer, The Netherlands: Kluwer and Taxation Publishers, 1990) at 164.

44 (1983) 8. Y.Comm. Arb. 158.

45 (1976) 1 Y. Comm. Arb. 128.
} 


\section{The Role of Transnational Public Policy}

The preceding discussion has focused on the restriction which mandatory rules of national law (rules which are reflective of the public policy of the enacting states) place on the application of the governing substantive law. However, while mandatory national rules may operate to dislodge the applicable substantive law, there is in international commercial practice a public policy superior to national public policy.

This pre-eminent public policy is sometimes labeled transnational public policy ${ }^{46}$ or truly international public policy. ${ }^{47}$ Like the concept of public policy in national law, the concept of transnational public policy presupposes the existence of "a certain community and of certain fundamental values." However, unlike national public policy, the relevant community here is not a national community but the international community.

While the public policy of a State embodies the moral and ethical philosophy of the State, transnational public policy performs the same role for the international business community. There is a certain similarity between the two: principles which embody the fundamental and ethical values of a national community would in a majority of cases be equally fundamental in the international community. For example, the requirement of fair hearing and due process is considered a basic element of justice in both the national and the international communities. However, so long as national public policy represents particular and narrow national interests, while transnational public policy represents the values of the world community, the two strands of public policy cannot be identical. For example, while the act of gambling is against public morals in some societies, it can hardly be said that the abhorrence of gambling is part of the fundamental values of the world community.

Transnational public policy represents the fundamental values, the basic ethical standards and enduring moral consensus of the international community. Its principles are jus cogens in public international law" ${ }^{48}$ and

\footnotetext{
${ }^{46}$ For a very helpful discussion of the role of transnational public policy in international commercial arbitration, see P. Lalive, "Transnational (or Truly International) Public Policy and International Arbitration” in P. Sanders, at 257.

${ }^{47}$ Lew, at 534.

48 According to J. Robert and T. Carbonneau, transnational public policy incorporates "principles sufficiently general to be recognised by a number of legal systems representing a bona fide community of civilised nations.” The French Law of Arbitration (New York: Mathew Bender, 1983) at 11:9-11. While the concept of civilised nations as
} 
the public policy accepted in a generality of nations. ${ }^{42}$ These principles, which include the abhorrence of racial, religious and sexual discrimination and the repudiation of corrupt practices, are in a sense the mandatory rules of international commercial relations which must be respected in all arbitrations.

The application of transnational public policy is seen as crucial to the maintenance of minimum standards of conduct and behaviour in international commercial relations. As the court of Appeal of Paris points out, "The security of international commercial and financial relations requires the recognition of a public policy which is, if not universal, at least common to the various legal systems." 49

Arbitrators are particularly suited to apply the principles to transnational public policy because they have a responsibility to maintain a certain element of equity and fair play in the international commercial arena and they are not guardians of the public policy of any particular State. This responsibility is partly discharged by their balancing the will of the parties with the legitimate interests of the international community in preserving the basic notions of contractual morality and justice.

Arbitrators, as guardians of the international commercial order, refuse to enforce a contract if it contravenes transnational public policy. This was the result in ICC Case No. $1110 . .^{50}$ In that case, the claimant claimed some money as commission for his efforts in helping the respondent procure an Argentinean government contract. Having determined that the commission amounted in violation of transnational public policy:

It cannot be contested that there exists a general principle of law recognised by civilised nations that contracts which seriously violate bonos mores or international public policy are invalid or at least unenforceable and that they cannot be sanctioned by courts or arbitrators. This principle is especially apt for use before international arbitration tribunals that lack a "law of the forum" in the ordinary sense of the term.

The arbitrator declined to proceed with the arbitration, holding that corruption involved in the transaction as "an international evil; it is contrary to good morals and to an international public policy common to the community of nations".

used by the authors is not free from controversy, the general idea is that transnational policy includes the synthesis of the public policy of a representative selection of nations.

${ }^{49}$ See P. Lalive, at 278.

${ }^{50}$ Reported by J. Lew, at 553. 
Also in ICC Case No. $2730^{51}$ the tribunal held that an agreement designed to contravene Yugoslav exchange control law was void because the contract was contrary "not only to Yugoslav law but also to morality and bonos mores."

Transnational public policy could also be a ground for an arbitrator's refusal to apply the mandatory rule of a relevant national law. Transnational public policy represents values that are superior to those of particular national systems. Therefore, when a mandatory national rule is in conflict with a transnational policy, the latter prevails, at least in an international arbitral forum. ${ }^{52}$ This is because arbitrators owe a paramount duty to the international community. Illustrating this principle, P. Mayer gives as an example certain boycott laws that establish restrictions on the grounds of race and religion. He rightly argues that an arbitrator should in the name of transnational public policy refuse to enforce such mandatory laws because they seek to institute racial or religious discrimination which contravenes transnational public policy.

It is useful to enter a caveat regarding the use of transnational public policy in refusing to apply national mandatory rules. If the use of this doctrine is not placed under careful and continual scrutiny, it may become a ready tool at the hands of Western jurists who wish to utilise this theory in refusing to recognise or apply those national laws which they deem unsuitable to their regional interests. Now and again one hears all sorts of rules being pleaded as part of transnational public policy, rules which at best are thinly disguised attempts to consecrate policies amenable to Western interest and rules of universal validity. For example, the doctrine of pacta sun servanda and the principle of good faith are often pleaded in support of an alleged principle of transnational policy which ordains the immutability of State contracts in the absence of a common agreement of the parties to alter the contractual provisions. This argument is made despite clear and readily accessible evidence that State practices in many jurisdictions (for example, State practices in France and those jurisdictions whose legal systems are modelled on the French) adopt the theory of administrative contracts whereby the State in municipal relations has, under certain conditions, extra-contractual powers to alter the provisions of a government contract. ${ }^{33}$

51 (1984) Clunet 914.

${ }^{52}$ See P. Mayer, at 291; J. Lew, at 104.

${ }^{53}$ See C. Turpin, "Public Contract" in International Encyclopedia of Comparative Law, Vol. 7 Contracts in General, Chapter 4 (The Hague: Tubingen \& Martinus Nijhoff, 1982). See also J. Mitchell, The contracts of Public Authorities: A Comparative study (London: G. Bell \& Sons Ltd.) 
It could then be seen that while the doctrine of transactional public policy is very useful in securing contractual morality in international commercial relations, it could easily become a political tool at the hands of imperial scholars and arbitrators. It is therefore important that third world scholars take particular note of this tendency, and work to ensure that transnational policy is only used to serve its declared and legitimate objective: the enforcement of those policies, standards and principles which truly represent a consensus of the world community, not just a segment, however powerful, of it.

In sum, the theory of transnational public policy originates from an attempt by arbitrators to enforce those fundamental ethical and moral values which are necessary for the security of international commercial relations. It is the case that the concept of transnational public policy is rarely raised before arbitrators as a ground for invalidating a contractual obligation. Nevertheless, its presence in arbitral practice is a reminder to potential arbitrating parties that the relative process could be used to circumvent the application of basic concepts of morality and justice.

\section{Conclusion}

Mandatory rules are one of the ways in which the doctrine of party autonomy is adapted to the legitimate interests of States in ensuring that the arbitral process affirms the basic elements of contractual morality. Of course, arbitrators are not expected to apply each and very mandatory rule that is pleaded as relevant to the case. Their mission in this regard is to examine the nature and purpose of relevant mandatory rules and ascertain whether the enacting State's connection with the parties' transaction warrants the application of such rules. Where the connection is limited or merely speculative, the arbitrator should decline to apply such rules. ${ }^{54}$

Arbitrators should also ensure that disputes before them conform to the requirements of transnational public policy.

The enforcement of appropriate mandatory rules by arbitrators would send a signal to prospective arbitrating parties that the arbitral process is certainly not a device for circumventing imperative laws of States with which their transaction is substantially connected. This attitude would justify the confidence of those States which believe that arbitrators are well suited to adjudicate claims involving sensitive matters of State policy.

\footnotetext{
${ }^{54}$ J. Enterria, “The Role of Public Policy in International Commercial Arbitration” (1990) 21 Law \& Policy Int’s Bus 389.
} 


\section{References}

Allison, "Arbitration of Private Antitrust Claims in International Trade: A subordination of National Interests to the Demands of a World Mardet” 18 N.Y.J.Int'1 L. \& Po1. 1986.

Anton, 1990. Private International Law, 2nd ed. Edinburgh: W. Green.

Asante, "Stability of contractual Relations in the Transnational Investment Process” 1979, 28 I.C.L.Q.

Avanessan, "The New York convention and Denationalised Arbitral Awards: with Emphasis on the Iran-United States Claims Tribunal" J. Int'1 Arb. 5, 1991, 8.

Baird "Self-Interest and Cooperation in Long-Term contracts" J. Legal Studies, 1990, 19.

Bartels, 1985. Contractual Adaptation and Conflict Resolution, The Netherlands: Kluwer Law and Taxation publishers.

Van Den Berg "The New York convention of 1958: cibsikudated cinnebtart", Y. Comm. Arb., 1989, 14. The New York Convention of 1958: Towards a Uniform Judicial Interpretation, The Netherlands: Kluwer Law and Taxation publishers, 1981.

Bermann and F. Dasser, 1990. "The 'New' Law Merchant and the 'Old': Source, Content, and Legitimacy" in T. Carbonneau (ed.) Lex Mercatoria and Arbitration (New York; Transnational Juris publications Inc. "National Law and Commercial Justice: safeguarding procedural Integrity in International Arbitration” 1989, 63 Tulane L.R. 647.

"Judicial supervision of Transnational Commercial Arbitration: The English Arbitration Act” (1980) 21 Hastings Int'1 L.J. 87.

Paulsson, "Arbitration Unbound: Award Detached from the Law of its Country of Origin” 1981, 30 I.C.L.Q. 358.

"Delocalisation of International Law to Repudiate consent of International Commercial Arbitration and why it Matters" 1983, 32 I.C.L.Q. 53.

"May a State Invoke its Internal Law to Repudiate Consent to International Commercial Arbitration” 1986, 2 Arb. Int'1 90.

"The Extent of the Independence of International Arbitration from the Law of the Situs” in J. Lew (ed.) Contemporary. 